\title{
Basement and cover architecture in the Central Pyrenees constrained by gravity data
}

\author{
P. Clariana ${ }^{1}$ (1) $\cdot$ R. Soto ${ }^{1} \cdot$ C. Ayala ${ }^{2} \cdot$ A. M. Casas-Sainz ${ }^{3} \cdot$ T. Román-Berdiel $^{3} \cdot$ B. Oliva-Urcia ${ }^{4} \cdot$ E. L. Pueyo ${ }^{1} \cdot$ E. Beamud $^{5}$. \\ C. Rey-Moral ${ }^{6} \cdot$ F. Rubio ${ }^{6} \cdot$ A. Margalef $^{7} \cdot$ S. Schamuells ${ }^{8} \cdot$ N. Bach $^{8} \cdot$ J. Martí $^{8}$
}

Received: 4 August 2020 / Accepted: 15 November 2021 / Published online: 3 December 2021

(c) The Author(s) 2021

\begin{abstract}
A new gravity survey (1164 gravity stations and 180 samples for density analysis) combined with two new geological cross sections has been carried out in a sector of the Central Pyrenees in order to improve the characterization of basement and cover architecture. From North to South, the study area comprises the southern half of the Axial Zone and the northernmost part of the South-Pyrenean Zone. New gravity data were combined with previous existing databases to obtain the Bouguer and residual anomaly maps of the study area. The two cross sections, oriented NNE-SSW, were built from field data and previous surficial and subsurface data and cross the La Maladeta plutonic complex. The residual anomaly map shows values ranging from -18 to $16 \mathrm{mGal}$ and anomalies mainly oriented N120E. The two 2.5D modelled cross sections show similar observed gravity curves coinciding with similar interpreted structural architecture. Data show a gravity high oriented N120E coinciding with the Orri basement thrust sheet and an important gravity depression, with the same orientation, coinciding with the leading edge at depth of the Rialp basement thrust sheet and interpreted as linked to a large subsurface accumulation of Triassic evaporites. The volume at depth of the La Maladeta and Arties granites has been constrained through gravity modelling. This work highlights that the combination of structural geology and gravity modelling can help to determine the structural architecture of an orogen and localize accumulations of evaporites at depth.
\end{abstract}

Keywords Gravimetric anomalies · Gravity-constrained cross sections · La Maladeta plutonic complex · Triassic evaporites · Central Pyrenees

P. Clariana

p.clariana@igme.es

1 Instituto Geológico y Minero de España (CN IGME-CSIC), Unidad de Zaragoza, Zaragoza, Spain

2 Instituto Geológico y Minero de España (CN IGME-CSIC), currently visiting researcher at Geosciences Barcelona, Barcelona, Spain

3 Geotransfer Research Group (IUCA), Universidad de Zaragoza, Zaragoza, Spain

4 Dpto. de Geología y Geoquímica, Universidad Autónoma de Madrid, Madrid, Spain

5 Paleomagnetic Laboratory CCiTUB/ICTJA CSIC, Barcelona, Spain

6 Instituto Geológico y Minero de España (CN IGME-CSIC), Madrid, Spain

7 Centre d'Estudis de la Neu i de la Muntanya d'Andorra, Institut d'Estudis Andorrans, Sant Julià de Lòria, Andorra

8 Geosciences Barcelona, CSIC, Barcelona, Spain

\section{Introduction}

The Pyrenees (Northeast of Spain and South of France) have attracted multitude of research during the past decades due to their excellent outcrops generating an extensive knowledge of its surface geology and map-based reconstructions. Regarding its subsurface geology, the ECORS-Pyrenees deep seismic reflection profile acquired during the 80 s provided the first image of the structure and reflectivity of the crust across the Central Pyrenees. The results show an asymmetric doubly verging thrust wedge that formed above the subduction of the Iberian crust under the European plate (Chokroune and ECORS Team 1989; Roure et al. 1989; Torné et al. 1989; Muñoz 1992). Since then, numerous geophysical studies have been performed, with different interpretations leading to quite contrasting crustal models (e.g. Chevrot et al. 2014, 2018; Wehr et al. 2018; Pedrera et al. 2017; Teixell et al. 2018; García-Senz et al. 2019; and references therein). 
In the central part of the chain, the internal architecture of the orogen consists of an antiformal stack of basementinvolved units dominated by Paleozoic rocks (Axial Zone) and two fold-and-thrust belts involving Mesozoic and Cenozoic units flanking the Axial Zone to the north and south (e.g., Muñoz 1992; Fig. 1). The Axial Zone is characterized by the presence of several Late Variscan igneous bodies emplaced in the Paleozoic metasedimentary succession (Zwart 1986; Barnolas et al. 1996). In large areas to the south of the Axial Zone, the Mesozoic and Cenozoic cover was decoupled from the basement along the Triassic evaporites, which act as the regional décollement. The subsurface structure of the Mesozoic and Cenozoic cover has been mainly constrained from the interpretation of seismic data and wells acquired during the 60s, 70s and 80s (e.g., Muñoz 1992; Vergés 1993; Teixell and Muñoz 2000; Muñoz et al. 2018). However, in the Axial Zone and leading edges, subsurface data are very scarce and the geometry of structures at depth is more speculative.

An efficient and cost-effective way to better constrain the subsurface structure in areas without seismic reflection and/ or wells is the use of potential field geophysics. Gravimetry is a geophysical technique sensitive to lateral density variations thus providing a constraint to reconstruct geometries at depth (e.g. Goleby et al. 1989; Ayala et al. 2019). Since Torné et al. (1989), several works including potential field modelling have been published trying to image the deep structure of the Pyrenees down to the lithospheric mantle (e.g., Adam 1993; Casas et al. 1997; Ledo et al. 2000; Vacher and Souriau 2001; Jammes et al. 2010; Pedrera et al. 2017, 2018; Chevrot et al. 2018; Wehr et al. 2018; GarcíaSenz et al. 2019) or focusing on the upper crustal structures covering more specific zones in the southern Pyrenees (e.g. Santolaria et al. 2016; Calvín et al. 2018).

Considering the density contrast between host rocks and granites in the basement and between evaporites and other sedimentary rocks in the cover along the Central Pyrenees, in this work we use a workflow that combines the construction of two geological cross sections and their corresponding gravimetric models (see also Santolaria et al. 2016, 2020; Izquierdo-Llavall et al. 2019). The aim of this work was to investigate the basement and cover architecture in the
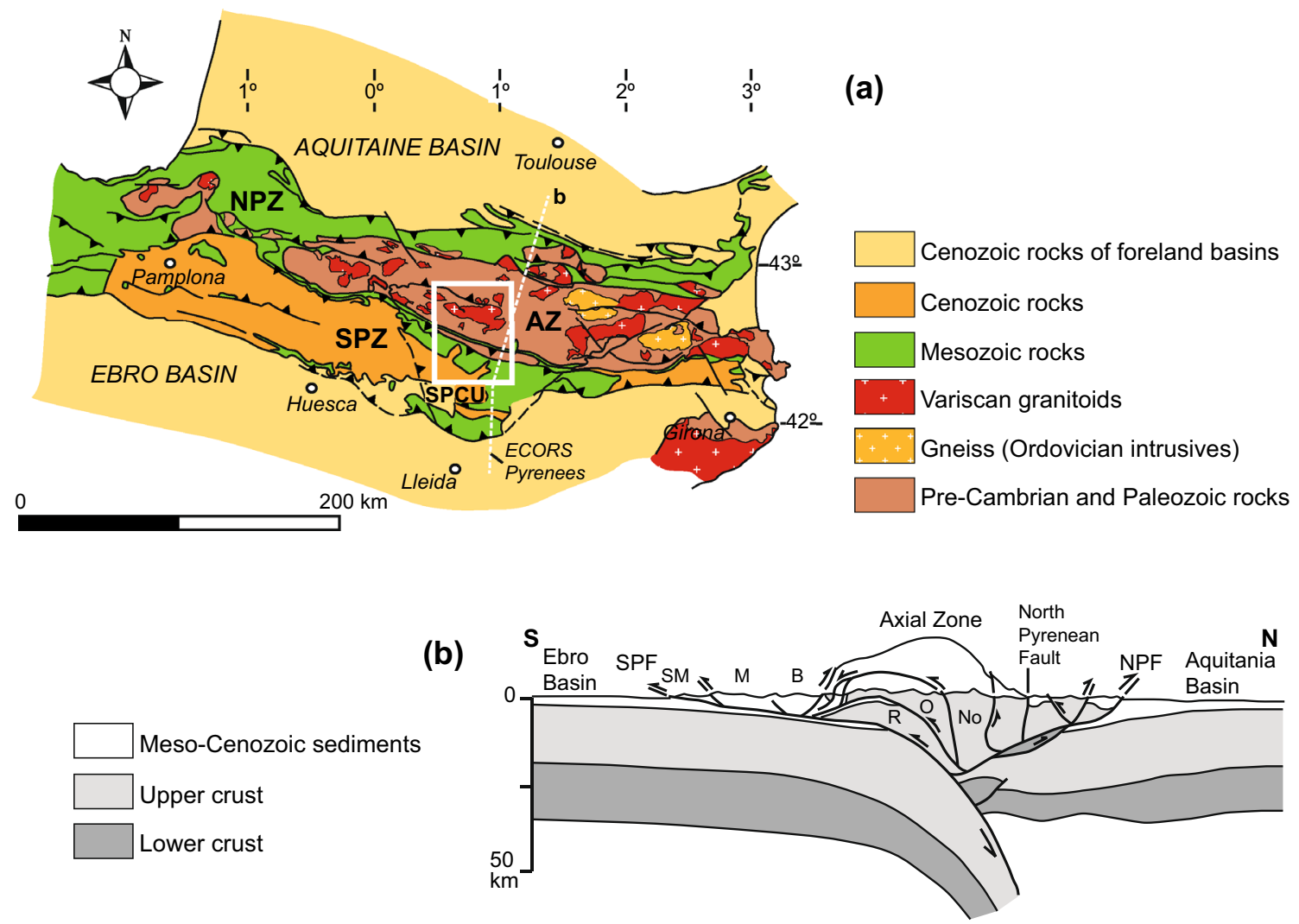

Fig. 1 a Geological sketch of the Pyrenees with location of the study area and the ECORS-Pyrenees profile. Structural Units: SPZ, South Pyrenean Zone; AZ, Axial Zone; NPZ, North Pyrenean Zone; SPCU, South Pyrenean Central Unit. (b) Geological interpretation of the ECORS-Pyrenees seismic profile according to Muñoz (1992). Thrust sheets: No, Nogueres thrust sheet; O, Orri thrust sheet; R, Rialp thrust sheet; B Bóixols thrust sheet; M, Montsec thrust sheet; SM, Sierras Marginales thrust sheet; SPF, South Pyrenean front; NPF, North Pyrenean front 
Central Pyrenees and to constrain the geometry at depth and the volumetric distribution of the Triassic evaporites and the La Maladeta batholith. Furthermore, we intend to test if the overall proposed geometry of the Central Pyrenees is consistent with the gravity data. The target area is a sector of the Central Pyrenees encompassing the southern half of the Axial Zone and the northernmost part of the SouthPyrenean Zone (Fig. 1). This area is key for understanding the role played by the Triassic evaporites on the mechanical decoupling between the basement and cover rocks.

\section{Geological setting}

The Pyrenees constitute an Alpine range that resulted from the collision between the Iberian and European plates from the Late Cretaceous to the Miocene (e.g. Muñoz 1992). It is an asymmetric doubly vergent orogen with a mainly southward vergence (e.g. Muñoz 1992) (Fig. 1b). Classically the range has been divided into the following three WNW-ESE trending structural zones (Mattauer 1968; Fig. 1a): (i) The North-Pyrenean Zone, (ii) the South-Pyrenean Zone, and (iii) the Axial Zone at the core of the range. The North-Pyrenean Zone mainly consists of Mesozoic sediments overlain by syncompressional Paleogene sediments (Déramond et al. 1988) characterized both by a mechanical coupling between Paleozoic basement and cover rocks (thick-skinned tectonics) in some sectors and a total decoupling resulting from the presence of a thick detachment level (clays and gypsum) at the Upper Triassic in other areas. The South-Pyrenean Zone is characterized by a thicker Paleogene syntectonic succession (e.g. Séguret 1972; Muñoz 1992), a clear southward vergence and a more generalized decoupled deformation between the cover and the basement. Deformation of the Pyrenean double-wedge progressed outward in a piggyback fashion, although synchronous inward internal deformation has been also documented (e.g. Muñoz et al. 1986; Vergés and Muñoz 1990). The Southern Central Pyrenees are characterized by a central antiformal stack of several southward-facing basement-involved thrust sheets (i.e. the Axial Zone) and an imbricate stack involving cover rocks (i.e. the South-Pyrenean Zone) (e.g. Muñoz 1992; Beaumont et al. 2000). This structural architecture responds to the interaction between a mid-crustal detachment effective for the basement-involved thrust sheets and the Triassic evaporites that decoupled deformation between the Mesozoic succession and the basement in the South-Pyrenean Zone (e.g. Muñoz 1992; Beaumont et al. 2000).

The Axial Zone is composed of several basement sheets whose number, name and distribution vary along-strike and from an author to another (e.g. Parish 1984; Williams 1985; Poblet 1991; Muñoz 1992; García-Sansegundo 1992; Teixell 1996; Martínez-Peña and Casas-Sainz 2003;
Labaume et al 2016; Izquierdo-Llavall et al. 2018; GarcíaSenz et al. 2019; Espurt et al. 2019). In this work, in the study area, we have considered the following main basement thrust sheets differentiated by Muñoz (1992): the Nogueres, Orri and Rialp thrust sheets (Fig. 1b) and the Ribagorza thrust sheet (Muñoz et al. 2018). They were progressively deformed by underthrusting of the lower and younger units (e.g. Muñoz 1992). The uppermost thrust sheet (the Nogueres Unit) was forward rotated and tilted in the southern limb of the antiformal stack showing downward facing structures (Séguret 1972; Muñoz 1992). Rocks belonging to basement thrust sheets were already deformed during the Variscan Orogeny (Middle-Late Carboniferous), whose main structural features were partly reactivated during the Alpine compression (e.g. Poblet 1991; García-Sansegundo 1996; Gil-Peña 2004). During the Alpine shortening, the Triassic evaporites acted as the upper décollement for the Axial Zone antiformal stack (i.e. roof thrust) (e.g. Muñoz 1992; Saura and Teixell 2006). Internally, the Silurian black shales also acted as a décollement both in the Variscan and Alpine Orogenies (Matte 1969; García-Sansegundo 1990; García-Sansegundo et al. 2011).

South of the Axial Zone in the Central Pyrenees, the Mesozoic-Cenozoic cover forms a large imbricate thrust system known as South Pyrenean Central Unit (SPCU; Séguret 1972) (Fig. 1a). The SPCU consists of three main thrust units (from top to base and in order of emplacement, Bóixols, Montsec and Sierras Marginales thrust sheets) (Fig. 1b) emplaced in a piggyback thrust sequence from the Late Cretaceous to the Oligocene. The study area only encompasses the northernmost unit, the Bóixols thrust sheet (Fig. 1a, b). The Bóixols unit resulted from the inversion of one of the main Lower Cretaceous extensional basins of the Pyrenees, the Organyà basin, from Late Santonian to Maastrichtian (Garrido-Megías 1973; Simó 1986; Bond and McClay 1995; García-Senz 2002). Between the Bóixols thrust sheet and the Axial Zone, it appears a sector, named Ribagorza basin (Fig. 2), characterized by several large Triassic salt diapirs (e.g. Aulet diapir) and a complex fault network (Teixell and Muñoz 2000; García-Senz 2002; Saura et al. 2016). The Ribagorza basin consists of a Cretaceous basin inverted during the Pyrenean orogeny (Saura et al. 2016). The Triassic evaporites, at the base of the Mesozoic succession, played a major role on the structural architecture both during the Mesozoic rifting and its posterior tectonic inversion (e.g. García-Senz 2002; Mencos et al. 2015; Muñoz et al. 2018). Southwards of the study area, Triassic outcrops are scarce and this unit re-appears in the large exposures located within the Sierras Marginales thrust sheet, the youngest unit of the SPCU. 


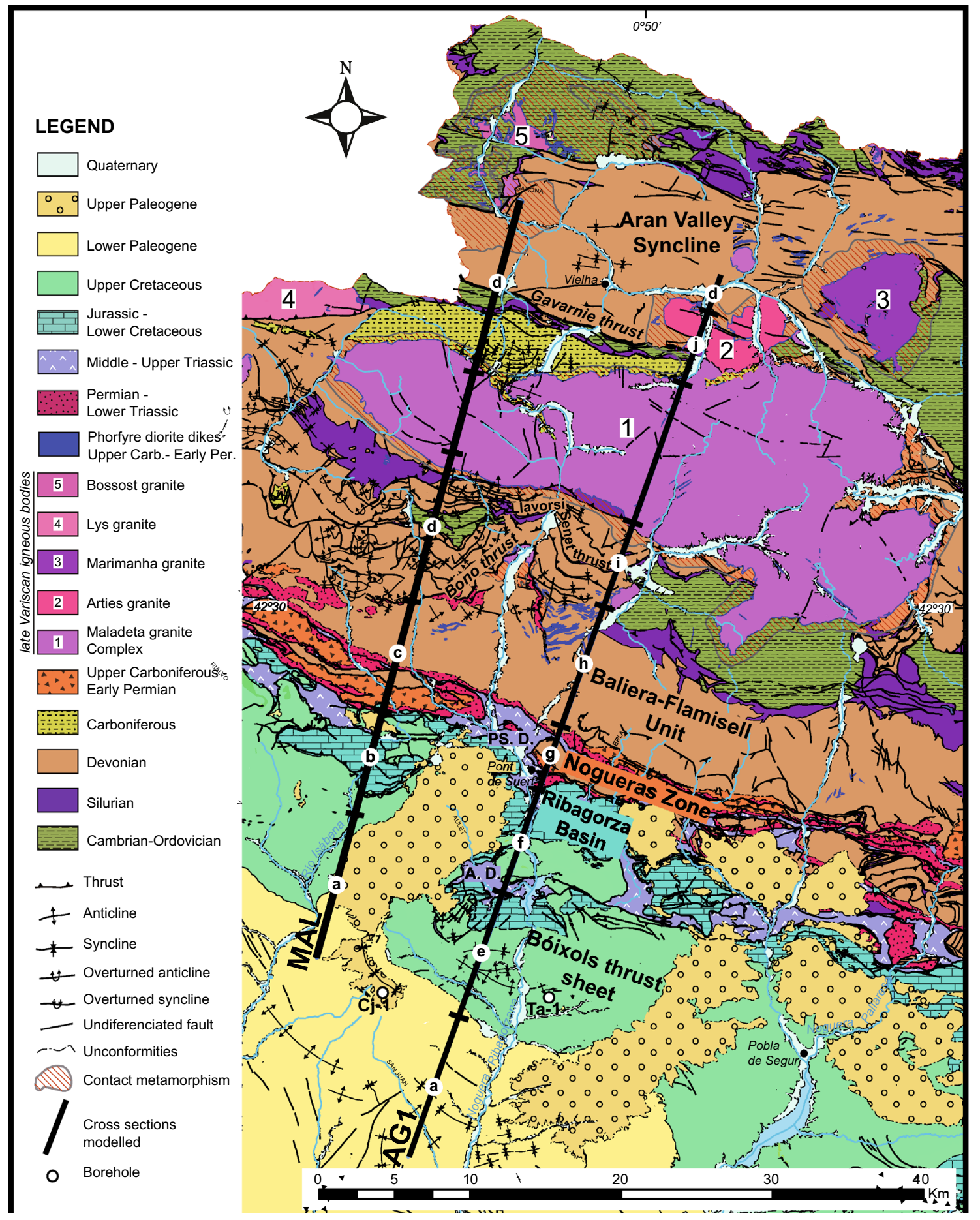

Fig. 2 Geological Map of the study area (modified from continuous digital geological map of Institut Cartogràfic y Geològic de Catalunya 2016) with location of the constructed cross sections and the available wells. These cross sections are divided in segments whose geometry at depth has been interpreted considering geological cross sections already published from different authors: a Teixell and
Muñoz (2000); b García-Senz and Ramirez-Merino (2009); c Izquierdo-Llaval et al. (2013); d García-Sansegundo (1992); e García-Senz (2002); f Saura et al. (2016); g Saura (2004); h Gil-Peña and Barnolas (2001); i Poblet (1991); j Soler et al. (1998). Boreholes: Cj-1, Cajigar-1; Ta-1, Tamurcia-1. Diapir outcrops: A.D, Aulet diapir; PS.D, Pont de Suert diapir 


\section{Stratigraphy}

The study area comprises a large variety of rocks both in age and lithology. In general terms, the oldest rocks (i.e. basement) crop out in the Axial Zone, located in the northern half of the study area, and the cover and younger sequences appear in its southern half (Fig. 2). The stratigraphy of the study area is described considering the division on geological units done for the gravity modelling based on their density values (see sixth section and Fig. 2).

The oldest rocks, Cambro-Ordovician in age, are a monotonous alternation of quartzites and slates with some intercalations of limestone and microconglomerate. Above, the Upper Ordovician sequence is mainly composed of siliciclastic rocks that lie unconformably upon the Cambro-Ordovician rocks (García-Sansegundo et al. 2004, 2011). In this work the Upper Ordovician sequence has been included within the Cambro-Ordovician unit. The Silurian rocks are represented by black shales that often acted as a décollement, conditioning deformation (Matte 1969; Poblet 1991; García-Sansegundo 1990, 1992, 1996). The Devonian units are mainly formed by slates and limestones (Zwart 1979). The youngest rocks of the variscan succession consist mainly of a siliciclastic package (Culm facies; Devolvé 1987). Upper Pennsylvanian and Permian rocks lie unconformably upon deeply eroded older rocks. The Upper Pennsylvanian units are mainly formed by andesitic lava flows and pyroclastic units with some intercalated coal beds. The Permian succession is made of sandstone, shales and microconglomerates (e.g. Mey et al. 1968; Gisbert 1983). In the study area several igneous bodies crop out (the La Maladeta plutonic complex, the Arties stock, the Marimanha pluton, the Bossòst leucogranite and the Lys-Caillaouas pluton) (Fig. 2). They intruded variscan rocks and some of them, including the La Maladeta body have been dated to be emplaced during the Late Carboniferous-Early Permian (Evans 1993; Solé et al. 1997; Esteban et al. 2015; Mezger and Gerdes 2016; López-Sánchez et al. 2019). The Triassic succession shows the following typical Germanic facies: Buntsandstein red beds, Muschelkalk dolostones and limestones and Keuper evaporites and shales. Hypabyssal rocks (dolerites) are relatively common within the Upper Triassic rocks (Lago et al. 2000). In this work, Upper Permian rocks and the Buntsandstein red beds have been grouped together and the Muschelkalk and Keuper are separated in a different unit.

The Jurassic and Lower Cretaceous sequences were deposited during a rifting period related to the opening of the Bay of Biscay and North Atlantic Ocean (e.g. Roca et al. 2011) and are represented by marine limestones and marls (Aurell and Meléndez 2002; García-Senz 2002). The
Upper Cretaceous sedimentary deposits consist of a succession of limestones, calcarenites and marls (Simó 2004) that registered an evolution from marine to transitional and finally continental environments (Puigdefàbregas and Souquet 1986; Puigdefàbregas et al. 1992). The limit between the Mesozoic and Cenozoic successions is located within a continental unit (Garumnian facies) consisting of red clays, sandstones and lacustrine limestones (Pujalte and Schmitz 2005). In this work we have merged this unit with the Lower Paleogene. This unit also comprises limestones, sandstones and marls belonging to the Graus-Tremp basin (Barnolas and Gil-Peña 2001). The youngest deposits considered in the study area, here included in the Upper Paleogene unit, are unconformable continental conglomerates deposited during Late Lutetian to Late Oligocene times (Beamud et al. 2011).

\section{Methodology}

Two parallel geological cross sections oriented NNE-SSW and separated approximately $12 \mathrm{~km}$ were built to infer the structural architecture of the study area (MAL and AG1; Fig. 2). They run perpendicular to the trend of the main geological structures. They were constructed using field data, surface geological data available from geological maps (Rosell 1994; Ríos-Aragües et al. 2002; García-Senz and Ramirez-Merino 2009; García-Sansegundo and Ramírez Merino 2013; Sanz-López and Palau 2013; López-Olmedo and Ardèvol 2016; Martín-Parra et al. 2016 and the geologic digital continuous map of Cataluña from Institut Cartogràfic i Geològic de Catalunya), as well as data from four nearby oil exploration wells (Tamurcia-1 -Ta-1-, Cajigar-1 -Cj-1-, Comiols-1 and Isona-1, Lanaja 1987). The two first boreholes (Fig. 2) reached the décollement level located on the Triassic evaporites and the other two (located to the South of the study area, out of the frame of Fig. 2) reach the autochthonous Eocene rocks allowing to know the minimum depth to the top of the basement (Teixell and Muñoz 2000). The geometry at depth interpreted by several geological cross sections already published by different authors was considered (references in Fig. 2).

Gravity data comes from the Institut Cartogràfic de Catalunya (CATAGRAV database 2010) and several gravity surveys carried out in the frame of GeoPiri3D project in 2018 and 2019 (Ayala et al. 2020) to improve the spatial resolution of the data. After merging the datasets (CATAGRAV, Ayala et al. 2020 and the newly acquired data), approximately 1 station every $\mathrm{km}^{2}$ is available surrounding La Maladeta and Arties granites, except in some areas above $2000 \mathrm{~m}$ a. s. 1. that were inaccessible by car (Fig. 3a). To have a homogeneous gravity data (Fig. 3b), we have calculated the complete Bouguer anomaly of 

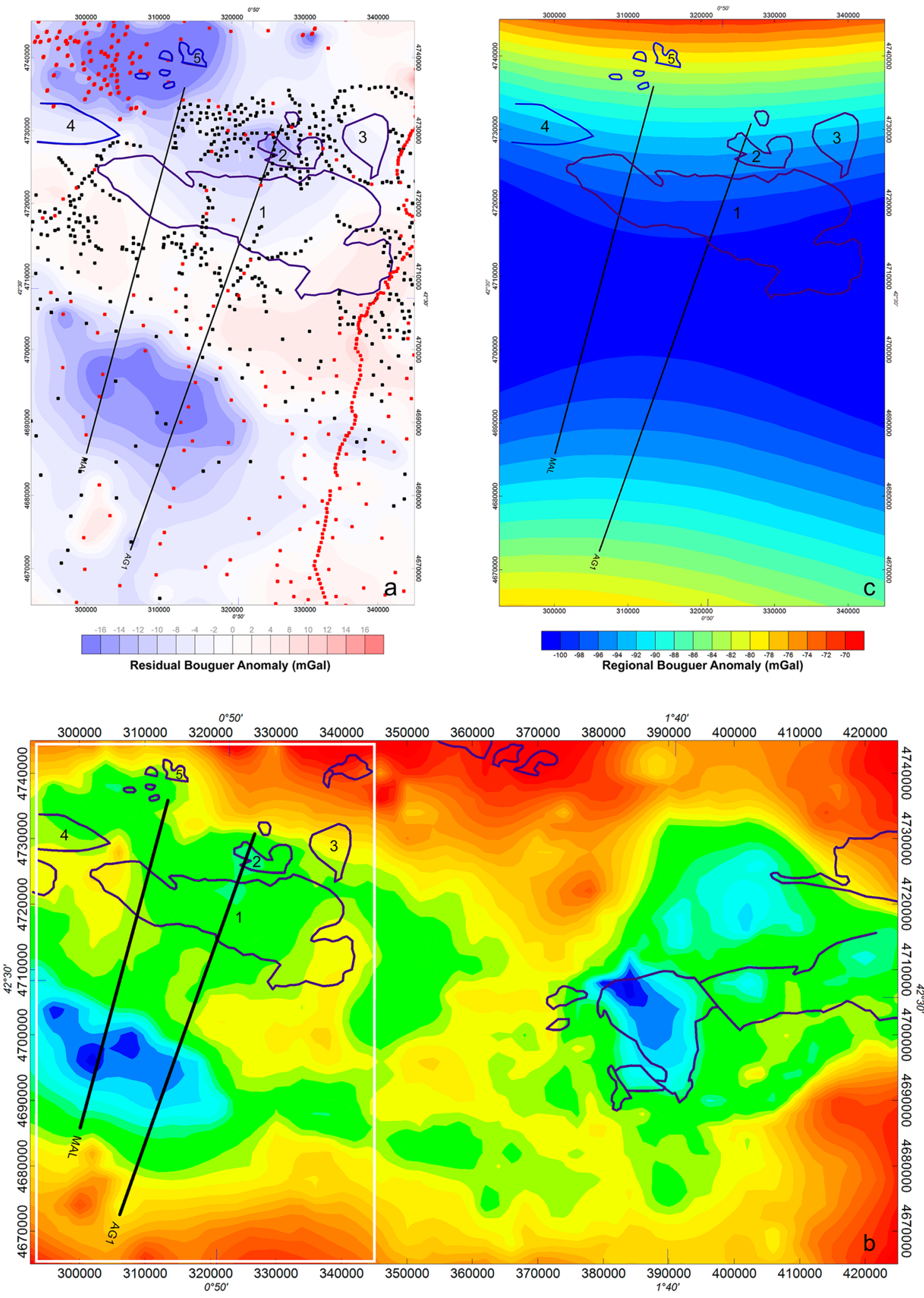

$\begin{array}{llllllllllllllllllllllll}-118 & -116 & -114 & -112 & -110 & -108 & -106 & -104 & -102 & -100 & -98 & -96 & -94 & -92 & -90 & -88 & -86 & -84 & -82 & -80 & -78 & -76 & -74\end{array}$ 
4Fig. 3 a Residual Bouguer anomaly map and distribution of the gravity stations by source: red circles indicate data from the CATAGRAV database (ICGC 2010); black circles correspond to data from Ayala et al. (2020) complemented in this study. Black lines indicate the location of the modelled cross sections. The contour lines correspond to La Maladeta (1), Arties (2), Marimanha (3), Lys-Caillaouas (4) and Bossost (5) granites. b Bouguer anomaly map of the Central Pyrenees modified from Ayala et al. 2020 showing location of the study area (white rectangle). $\mathbf{c}$ Regional anomaly of the study area

the new data with the same parameters of the following databases: GRS 80 geodetic system formulae, orthometric heights and a density reduction of $2.67 \mathrm{~g} / \mathrm{cm}^{3}$. The following corrections were applied to the theoretical gravity to obtain the Bouguer anomaly of the new data: free-air correction, Bouguer slab correction and terrain correction. The terrain correction was applied up to $167 \mathrm{~km}$ using the Oasis Montaj ${ }^{\circledR}$ terrain correction module that is based on Kane (1962) and Nagy (1966) algorithms, using a combined $5 \mathrm{~m}$ DTM from Spain, France and Andorra that were regridded to $30 \times 30 \mathrm{~m}$. as local grid and a combined grid from SRTM database and bathymetry data from GEBCO database regridded to $100 \times 100 \mathrm{~m}$ as regional grid. To carry out the analysis and interpretation of the Bouguer anomaly, we have gridded the data with a grid spacing of $1000 \mathrm{~m}$ using the minimum curvature method.

The cross sections were improved through the 2D-2.5D gravity modelling in a feed-back process between the geological and gravimetric modelling until the gravimetric response of the models fitted the observed gravity data. Based on the geological surface data and taking into account the aim of this study, we decided to limit the lateral extent only of the outcropping plutonic rocks that have clear boundaries with the host rocks, so only the La Maladeta granite has been modelled in $2.5 \mathrm{D}$ while the host rocks and all other units have been modelled in 2D. Along MAL cross-section, La Maladeta granite has a lateral extension of $8.57 \mathrm{~km}$ to the $\mathrm{W}$ and $32.64 \mathrm{~km}$ to the E. Along AG1 cross-section, the extension of La Maladeta granite is $21.18 \mathrm{~km}$ to the $\mathrm{W}$ and $19.57 \mathrm{~km}$ to the $\mathrm{E}$. The modelling was performed using the GM-SYS module of the Oasis Montaj ${ }^{\circledR}$ software by Seequent based on the Talwani et al. (1959) and Won and Bevis (1987) algorithms. The models were extended far enough to avoid edge effects. Since the target was the upper crust, we have used the residual Bouguer anomaly as observable.

\section{Bouguer and residual anomaly maps}

The new Bouguer anomaly map used in this paper (Fig. 3b) is characterized by a long wavelength elongated minimum of roughly E-W direction that occupies the central part of the study area with an amplitude of ca. $-100 \mathrm{mGal}$. This minimum, associated with the crustal root of the Pyrenees (e. g. Torné et al. 2015), seems to continue towards the W and closes towards the E (outside of the study area), presenting on the edges a positive gradient reaching Bouguer anomaly values up to $-65 \mathrm{mGal}$. Different relative maxima and minima of medium and short wavelengths with variable amplitudes are superimposed on this minimum and can be associated with shallower structures.

La Maladeta granite is a massive batholith that crops out in the central Pyrenees. The Bouguer anomaly over the La Maladeta granite outcrop shows variations in amplitude of only $12 \mathrm{mGal}$ (Fig. 3b). There are other smaller granites in this area whose outcrops are associated with a gravimetric minimum. One of them is the Arties granite (Fig. 3b), to the north of the La Maladeta granite, that is characterized by a relative minimum of -100 to $-108 \mathrm{mGal}$ within the northern gradient zone. The relative minimum located to the SW of La Maladeta has been interpreted as the gravimetric response of Triassic evaporitic accumulations far greater than the mapped outcrops.

The residual anomaly (Fig. 3a), that reflects the structures of the upper crust which are the targets of our study, was calculated by subtracting from the Bouguer anomaly, a regional anomaly that we assumed to correspond to a third degree polynomial (Fig. 3c). Focusing on the study area, La Maladeta granite shows a gravimetric zonation with small variations in its amplitude from one zone to the next (from 6 to $-10 \mathrm{mGal}$ ) (Fig. 3a), consistent with lateral changes in its composition, predominantly granodioritic (Debon et al. 1996). The anomaly over the Arties granite has a minimum that reaches ca. $-9 \mathrm{mGal}$, located in its westernmost part. From there, the anomaly increases steadily towards the borders with a rather gentle gradient reaching values up to $-2 \mathrm{mGal}$. The relative minimum with WNW-ESE orientation associated with the Triassic evaporites is one of the most prominent features of the residual map with a total amplitude of ca. $15 \mathrm{mGal}$ (Fig. 3a).

\section{Density measurements}

The characterization of the rock density is fundamental in gravity surveys to constrain the modelling thus reducing the uncertainties in the modelled geometry (e. g. McCulloh 1965; Santolaria et al. 2016; Izquierdo-Llavall et al. 2019). The densities were measured from rock samples of the different lithologies represented in the two cross sections. A total of 180 samples were collected from non-weathered outcrops which represent the whole range of geological units cropping out within the study 
area (many of them compiled in Ayala et al. 2020). Bulk density was measured using the double weighting method (standard UNE-EN 1936:2007), by weighing irregular samples weighting between 1000 and $2000 \mathrm{~g}$ in air and water (Archimedes principle). Taking into account these density values and previously published density data in the Pyrenees (Santolaria et al. 2016, 2020, for the Cenozoic units), we divided the stratigraphic succession of the modelled cross sections into 13 geological units (see Table 1). Individual sample density values range from $1.93 \mathrm{~g} / \mathrm{cm}^{3}$ (Middle-Upper Triassic evaporites) to $3.03 \mathrm{~g} /$ $\mathrm{cm}^{3}$ (Devonian metamorphosed slates and limestones). The density values used in the gravity modelling are plotted in the histograms of Fig. 4 where the range, mean and standard deviation of each geological unit have also been displayed together with a graph showing the percentage of the different lithologies (Fig. 4, Table 1). Available subsurface density data of Jurassic $\left(2.7 \mathrm{~g} / \mathrm{cm}^{3}\right)$ and Cretaceous $\left(2.65-2.7 \mathrm{~g} / \mathrm{cm}^{3}\right)$ limestone from borehole Cajigar 1 (Lanaja 1987; Santolaria et al. 2016) (Cj-1 in Fig. 2) confirm that the subsurface density values are similar to the outcropping samples. Additionally, the petrophysical data used in the modelling are similar, with very few exceptions, to the data obtained in similar studies carried out in other areas of the Northeast of Iberian Peninsula such as the Iberian Ranges (ca. 1500 points) (Pueyo et al. 2016).

To build the $2 \mathrm{D}-2.5 \mathrm{D}$ gravity models and to fit the gravity anomalies over the models, we choose density values as close as possible to the mean values of each unit and always within the range up to $\pm 0.23 \mathrm{~g} / \mathrm{cm}^{3}$ std dev (see Table 1).

\section{Gravity-constrained cross sections}

\section{Geological structure based on previous studies}

The overall structure observed from the constructed cross sections in the study area shows that almost all structures have a southern vergence. The geological structure and internal architecture of both cross sections are similar in terms of the position, number and characteristics of major structures and thrust sheets. Both cross sections display the same inhomogeneous coverage by geophysical data. In the South, the geometry at depth of the Bóixols thrust sheet has been well established by several authors based on seismic data and wells (Teixell and Muñoz 2000; García-Senz 2002; Mencos et al. 2015; Saura et al. 2016; Muñoz et al. 2018). However, in the Axial Zone only seismic data obtained from the ECORS-Pyrenees deep seismic reflection profile are available and most structural interpretations are mainly based on field data (e.g. Poblet 1991; García-Sansegundo 1992).

With respect to the Axial Zone, in the study area, its structure is defined by north-dipping thrusts with intermediate to steep dips that cut across, or re-activate Variscan structures (Gil-Peña 2004; Cochelin et al. 2017) (Fig. 5). Alpine structures involving the Paleozoic rocks are in general parallel to the Variscan fabric showing E-W to ESE-WNW trend and northward dip (Poblet 1991; García-Sansegundo 1992; Gil-Peña 2004; Gutierrez-Medina 2007). In the study area, the Axial Zone is formed by the following four basement thrust sheets that from top to bottom in the pile: Nogueres, Orri, Rialp and Ribagorza thrust sheets (Muñoz et al. 2018)

Table 1 Range, mean and standard deviation values of the density for each geological unit

\begin{tabular}{|c|c|c|c|c|c|c|c|}
\hline \multirow[t]{2}{*}{ Units } & \multirow[t]{2}{*}{$N$} & \multirow[t]{2}{*}{ Mean $\left(\mathrm{g} / \mathrm{cm}^{3}\right)$} & \multirow[t]{2}{*}{ Mode $\left(\mathrm{g} / \mathrm{cm}^{3}\right)$} & \multirow{2}{*}{$\begin{array}{l}\text { Standard } \\
\text { deviation } \\
\left(\mathrm{g} / \mathrm{cm}^{3}\right)\end{array}$} & \multirow[t]{2}{*}{ Range $\left(\mathrm{g} / \mathrm{cm}^{3}\right)$} & \multicolumn{2}{|c|}{ Range in the models $\left(\mathrm{g} / \mathrm{cm}^{3}\right)$} \\
\hline & & & & & & AG1 & MAL \\
\hline Cambro-Ordovician & 6 & 2.67 & - & 0.13 & $2.42-2.76$ & 2.7 & $2.65-2.7$ \\
\hline Silurian & 11 & 2.47 & - & 0.17 & $2.16-2.74$ & $2.47-2.6$ & $2.4-2.65$ \\
\hline Devonian & 39 & 2.69 & 2.69 & 0.13 & $2.41-3.03$ & 2.7 & $2.65-2.70$ \\
\hline Carboniferous-pre Stefanian & 4 & 2.68 & - & 0.013 & $2.67-2.7$ & 2.68 & 2.68 \\
\hline Upper Carboniferous-Early Permian & 26 & 2.53 & 2.57 & 0.15 & $2.07-2.82$ & 2.6 & $2.6-2.63$ \\
\hline Permian-LowerTriassic & 11 & 2.63 & 2.69 & 0.06 & $2.5-2.69$ & 2.63 & 2.63 \\
\hline Upper Triassic & $19-1$ & 2.41 & 2.47 & 0.23 & $1.93-2.85$ & 2.4 (ofites 2.7 ) & 2.4 \\
\hline Jurassic-Lower Cretaceous & 7 & 2.69 & 2.65 & 0.06 & $2.65-2.78$ & $2.65-2.69$ & 2.69 \\
\hline Upper Cretaceous & 10 & 2.56 & 2.69 & 0.11 & $2.34-2.69$ & $2.62-2.66$ & 2.65 \\
\hline La Maladeta and Arties granites & 48 & 2.65 & 2.64 & 0.093 & $2.29-2.9$ & $\begin{array}{l}2.65(\mathrm{La} \\
\text { Maladeta)/2.6 } \\
\text { (Arties) }\end{array}$ & $\begin{array}{c}2.65 \text { (La Mal- } \\
\text { adeta) / } 2.6 \\
\text { (Arties) }\end{array}$ \\
\hline Lower Paleogene (Santolaria et al. 2016) & 145 & 2.57 & & & $2.55-2.65$ & 2.6 & 2.6 \\
\hline Upper Paleogene (Santolaria et al. 2016) & & 2.58 & & & & 2.6 & 2.6 \\
\hline $\begin{array}{l}\text { Autochthonous (Santolaria et al. 2016; } \\
\text { Muñoz et al. 2018) }\end{array}$ & & & & & & 2.65 & 2.65 \\
\hline
\end{tabular}



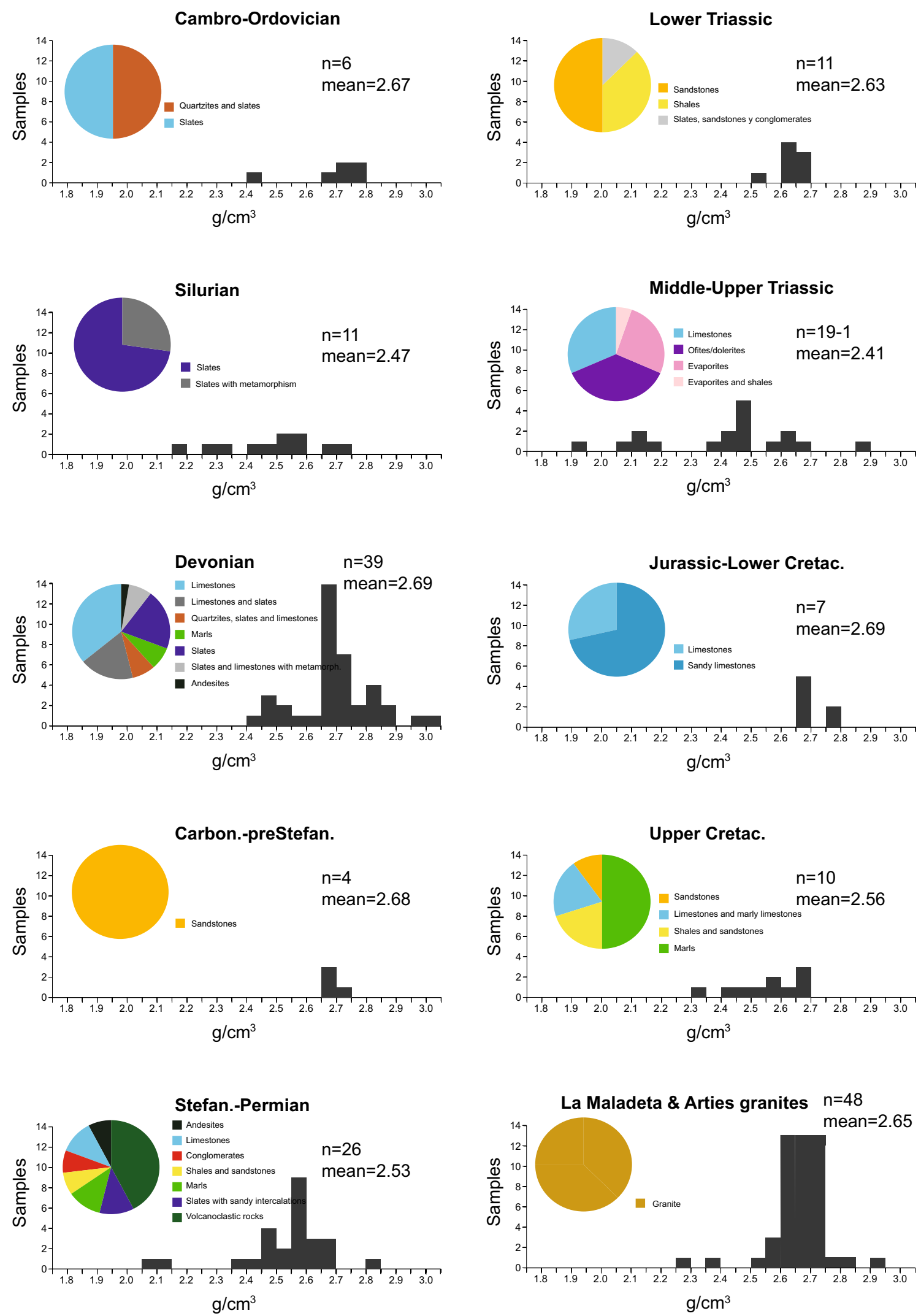

Fig. 4 Frequency diagrams of density measurements of main geological units of the study area used in the modelled cross sections. Density data of Lower Paleogene and Upper Paleogene units come from Santolaria et al. (2016) 

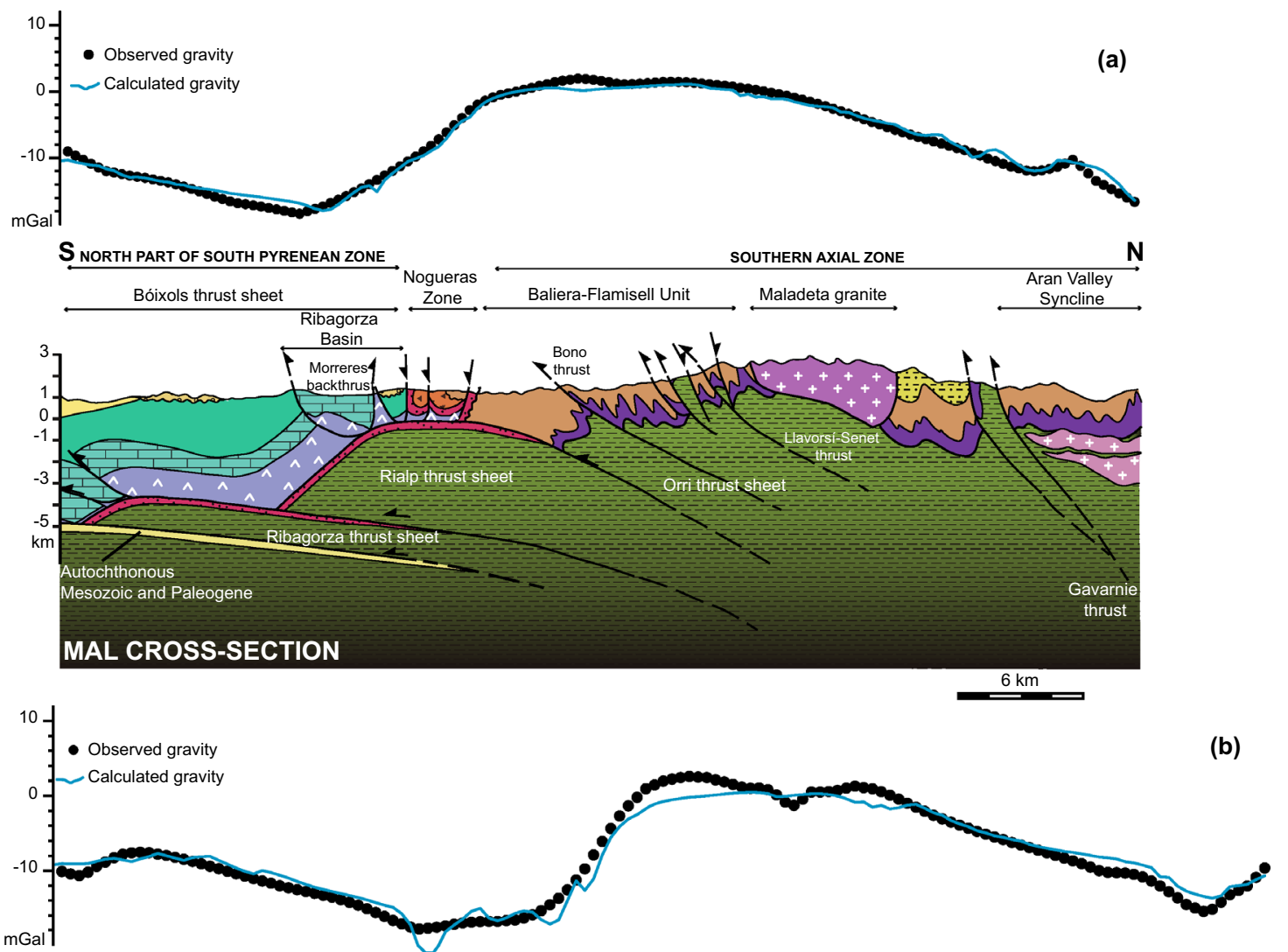

(b)

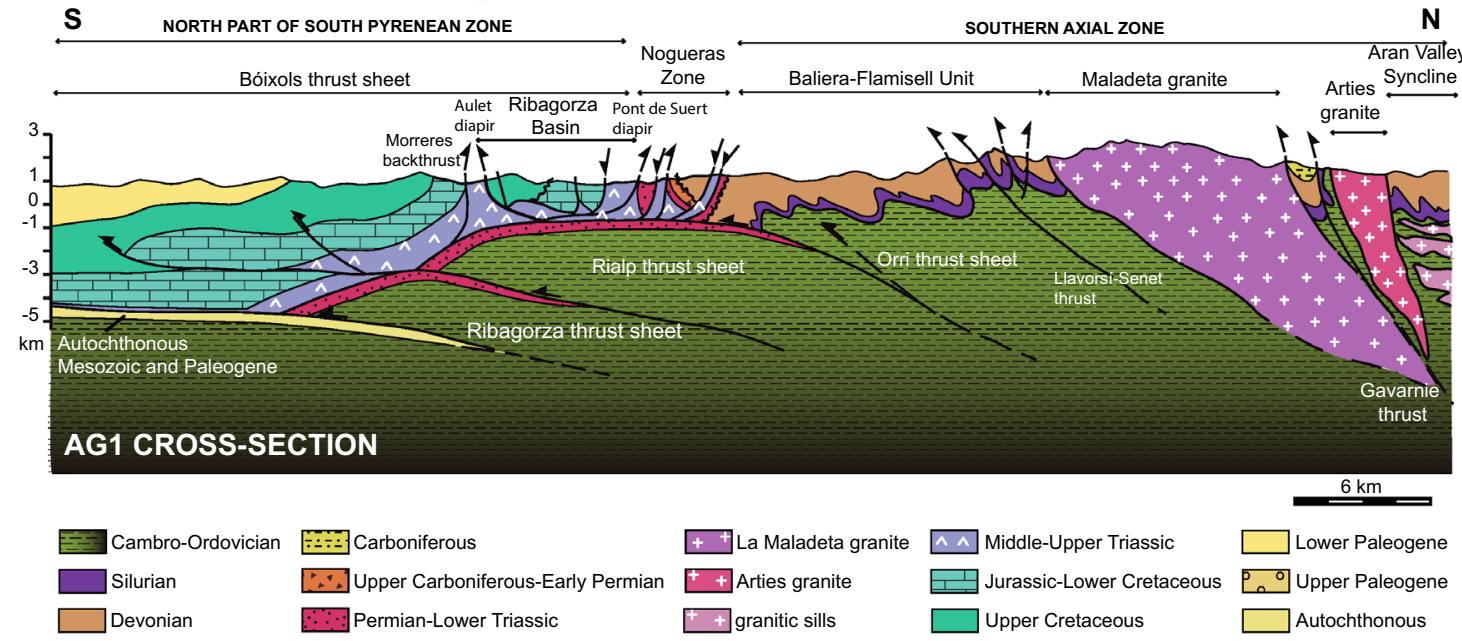

Fig. 5 a Observed and calculated gravity data and corresponding 2.5D model of cross section MAL; b Observed and calculated gravity data and corresponding 2.5D model of cross sections AG1, (see location in Fig. 2)

(Fig. 5). The northern basement thrust sheets show steeper dips than the southern ones (Muñoz 1992; Teixell et al. 2018).

The upper basement thrust sheet in the study area is the Nogueres thrust sheet (Figs. 1, 5). The Nogueres Unit was emplaced during the Late Cretaceous-Middle Eocene and was progressively deformed by the stacking of the lower and younger units (Muñoz 1992; Vergés et al. 1995; Saura 2004). As a consequence of this deformation, the structures of this thrust sheet were tilted in the southern limb of the antiformal stack showing downward facing folds (the socalled têtes plongeantes; Séguret 1972) that characterize the Nogueres Zone (Muñoz 1992) (Fig. 5). In the study area, the Nogueres Zone displays two small thrust slices involving Paleozoic (Devonian rocks, Upper Pennsylvanian volcanic rocks and Permian red beds) and Triassic rocks (red beds and dolostones) (Muñoz 1992; Saura 2004). The Nogueres Zone has been interpreted to be rooted in different 
structures located to the North. Muñoz (1992) proposed that the root of the allochtonous Nogueres Zone corresponds to the Gavarnie thrust (Figs. 2, 5), implying a large displacement along this thrust. This interpretation is discussed by Soler et al. (1998), Laumonier (2015) and Cochelin et al. (2017), who interpret that the Gavarnie thrust had a much lower displacement. Recently, Teixell et al. (2018) proposed that the root the Nogueres Zone is located in the North Pyrenean Fault, interpreted as a south directed thrust steepened by later deformation. Nevertheless, an important drawback for this hypothesis is that at present the hanging wall of this fault is only constituted by post Paleozoic rocks. Thus, the root of the Nogueres thrust sheet is nowadays still a matter of debate. The Gavarnie thrust crops out in the northern part of both cross sections (Fig. 5). It separates Devonian-Silurian slates and limestones of the Aran Valley syncline in the hanging wall from Cambro-Ordovician slates and quartzites in the footwall (Fig. 5), representing a stratigraphic omission (Soler et al. 1998; García-Sansegundo and Ramírez Merino 2013). In cross section MAL (Fig. 5) highly deformed Devonian rocks affected by contact metamorphism (García-Sansegundo 1992) crop out in the hanging wall of the Gavarnie thrust, whereas in cross section AG1 the Arties granite appears (Fig. 5).

The Orri thrust sheet (Muñoz 1992) is well exposed in the study area containing large outcrops of Cambro-Ordovician to Lower Carbonifeous rocks unconformably overlain by discontinuous outcrops of Lower-Middle Triassic red beds and intruded by the La Maladeta granite. The Orri thrust sheet groups three main south-directed thrusts, the Orri s.s. (outcropping to the east of the study area), Bono and Llavorsí-Senet thrusts (Poblet 1991; Muñoz 1992; GarcíaSansegundo 1996; Saura and Teixell 2006). The Bono thrust represents an Alpine structure and crops out in cross section MAL (Fig. 5). It superimposes Lower Devonian rocks over Lower-Middle Devonian rocks and Lower Triassic red beds (Figs. 2, 5) (Gutierrez-Medina 2007; Izquierdo-Llaval et al. 2013). Eastward, in the cross section AG1, this thrust is not recognized at surface (García-Senz and Ramirez-Merino 2009). The Llavorsí-Senet thrust crops out in cross section AG1 to the South of the La Maladeta granite (Figs. 2, 5). It is variscan in age and reactivated during late-variscan and alpine phases as demonstrated by the cross-cutting relations with the contact metamorphic aureole of the La Maladeta granite (Poblet 1991). The northern sector of the Orri thrust sheet, between the Gavarnie thrust and the La Maladeta granite, involves Lower Carboniferous rocks characterized mainly by a siliciclastic sequence "Culm facies" affected by variscan deformation (García-Sansegundo 1992) (Figs. 2, 5). The La Maladeta granite, whose gravimetric characterization will be detailed in the next section, is much larger in cross section AG1 (Fig. 5). To the South of the La Maladeta granite and still located in the Orri thrust sheet, the
Baliera-Flamisell Unit (Mey 1967; Mey et al. 1968) can be differentiated. This unit is mainly composed of outcropping Silurian and Devonian rocks deformed by two Variscan deformation phases and some Alpine thrusts (e.g. the Bono thrust) (Poblet 1991; Gil-Peña and Barnolas 2001). The most conspicuous structures in this unit were formed in the second phase of Variscan deformation and are characterized by east-west-trending upright to inclined folds and thrust faults. These thrust emanate from detachment levels located in different stratigraphic positions, both within the Silurian shales and within the Cambro-Ordovician rocks (GarcíaSansegundo 1990, 1992, 1996; Poblet 1991; García-Sansegundo et al. 2011).

The younger basement thrust sheets, the Rialp and Ribagorza thrust sheets, do not crop out in the study area. The leading edges at depth of these younger basement thrust sheets are located below the cover thrust sheets (Teixell and Muñoz 2000; Muñoz et al. 2018) (Fig. 5). These positions have been constrained taking into account (i) the depth of the autochthonous Paleogene succession drilled by the Comiols- 1 and Isona- 1 wells (located to the South of the study area), (ii) the thickness variations of the Mesozoic units and (iii) the identification of seismic reflectors related to the Bóixols unit (Teixell and Muñoz 2000; Muñoz et al. 2018). In this work the leading edges of both basement thrust sheets have been refined based on gravity data.

The Mesozoic succession of the study area is characterized by a widespread layer of Triassic evaporites at the base (Muñoz 1992; Teixell and Muñoz 2000; Muñoz et al. 2018). Cross sections go across the inverted Ribagorza basin (Saura et al. 2016) and the Bóixols thrust sheet, where a complex passive backthrust develops near its boundary with the Axial Zone (Morreres backthrust; Muñoz 1992). Triassic diapirs in the Ribagorza basin show large outcrops and a complex inner structure in which basic hypabyssal rocks (dolerites; locally called "ofites") are relatively common (Lago San José and Pocoví-Juan 1980; Saura et al. 2016), but despite their high density do not show a gravimetric signature due to their small volume. The thickness of the Mesozoic succession increases notably towards the South in these cover thrust sheets (Teixell and Muñoz 2000; García-Senz 2002) (Fig. 5). The Bóixols thrust sheet is bounded by the southdirected Bóixols thrust, which corresponds to a blind structure in the study area. The southern termination of both cross sections displays Paleogene rocks lying unconformably above strata of the previous units (Fig. 5).

\subsection{D gravity modelling}

The geological cross-sections MAL and AG1 were further constrained by means of $2.5 \mathrm{D}$ gravity modelling. The RMS (Root Mean Square) of the final models is $1.1 \mathrm{mGal}$ for the MAL profile and $1.6 \mathrm{mGal}$ for the AG1 profile. 

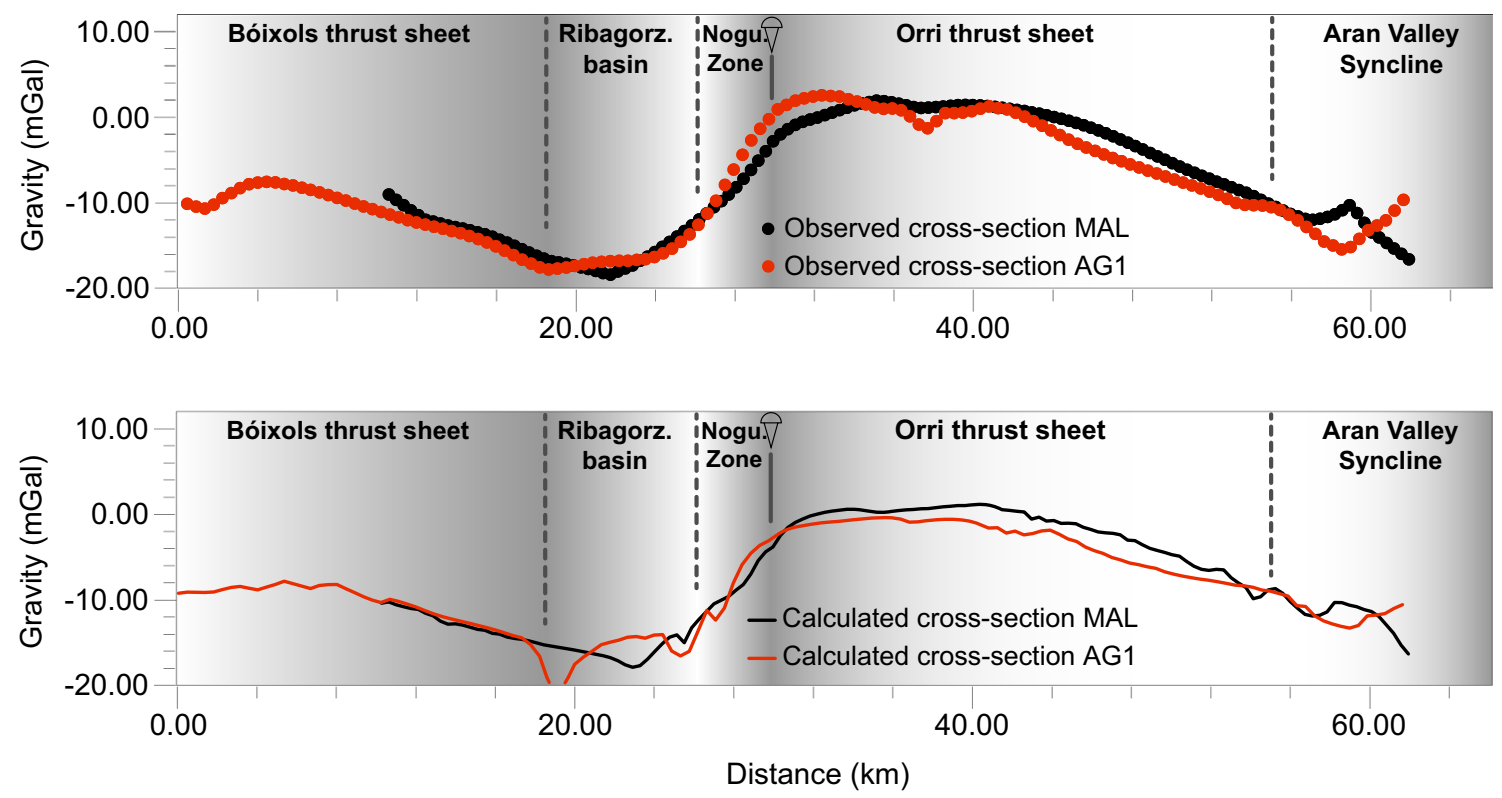

Fig. 6 Superposition of curves of observed and calculated gravity data for both cross-sections. Fixed points marked by pins are in the major structure separating the Nogueres Zone and the Orri

The observed gravity data (residual gravity) display a similar pattern along both cross sections (upper part of Fig. 6), which matches well with our interpretation of a similar structural architecture for both cross sections. The observed gravity curves show a relative gravity maxima (up to $2.4 \mathrm{mGal}$ ) coinciding with the Orri basement thrust sheet and an important relative gravity minima $(-18 \mathrm{mGal}$ in cross section MAL and $-17 \mathrm{mGal}$ in cross section AG1) coinciding with the southern termination at depth of the Rialp basement thrust (Fig. 5).

The wide gravity high of the Orri basement thrust sheet shows a roughly flat geometry located between the southern end of the La Maladeta granite and the beginning of the Nogueres Zone that coincide with the Baliera-Flamisell Unit (Figs. 5, 6). This zone of the profile belongs to a N120E elongated anomaly that ranges from -2 to $3.8 \mathrm{mGal}$, as can be seen on the residual anomaly map shown in Fig. 3a. It correlates with large outcrops of Devonian rocks deformed by numerous south-vergent folds and thrusts and at depth with thinner Devonian and Silurian layers and shallow Cambro-Ordovician sequences (ca. $1000 \mathrm{~m}$ below the surface), as deduced from the gravity model. Towards the North, the gravity high shows a gradual decrease in the observed gravity data from the southern end of the La Maladeta granite to the North (Figs. 2, 5, 6). The negative (absolute) values are lower in cross section MAL with respect to cross section AG1 (Fig. 6). This negative decrease is compatible with a granitic floor deepening towards the North in both cross sections. Over the La Maladeta granite the values of thrust sheet. This continuous structure is nearly perpendicular to the cross sections lines. The dash lines mark the approximate boundary between units because we have both cross sections together

the anomaly are lower along profile AG1 than along profile MAL (Fig. 6). In cross-section MAL the observed gravity data above the La Maladeta granite are compatible with a granitic body $1 \mathrm{~km}$-thick at the southern border that reaches almost $3 \mathrm{~km}$ depth in the North. In cross section AG1, the granitic body is larger, $2 \mathrm{~km}$ to almost $8 \mathrm{~km}$-thick from South to North. In the northern end of cross section AG1 a minimum $(-15 \mathrm{mGal})$ coincide with the outcrop of the Arties granite (Fig. 5b). The amplitude of this gravity low is compatible with a $6.5 \mathrm{~km}$-deep elongated geometry for this granite as the calculated gravity data show after performing the $2.5 \mathrm{D}$ gravity modelling. In cross-section MAL, despite the absence of granite outcrops there, the observed gravity values are even lower (below $-16 \mathrm{mGal}$ ) (Fig. 6). This gravity response is compatible with the presence of large volumes of granitic sills at depth as we have modelled to fit the calculated with the observed gravity data. This interpretation is based on the presence of the Bossòts Late Variscan granite (López-Sánchez et al. 2019) further north of the study area where big number of pegmatitic sills and veins crop out around of the main granitic body. In both cross sections, but more pronounced in cross section MAL, a relative small maximum, but still with negative values, appears at their northern sectors (Figs. 5, 6). This feature has been interpreted to be associated with higher values of density of Devonian rocks affected by a higher metamorphic grade (staurolite-cordierite-andalucite zone) in that area (García-Sansegundo 1992; García-Sansegundo and Ramírez Merino 2013). 
The observed gravity data display an abrupt decrease coinciding with the beginning of the Nogueres Zone in both cross sections. This decrease reflects a wide negative anomaly of a total amplitude of ca. $15 \mathrm{mGal}$ also oriented N120E (Fig. 3b) coinciding with the Nogueres Zone, the Ribagorza basin and the northern part of the Bóixols unit. It also correlates with the leading edge of the Rialp basement thrust sheet. In cross section AG1, the lowest gravity values ( -18 mGal) coincide with the Aulet diapir (i.e. Triassic evaporites) (Figs. 2, 5b), whereas, in cross-section MAL, the lowest gravity values (also $-18 \mathrm{mGal}$ ) do not correspond with Triassic evaporites outcrops at surface (Fig. 5a). The amplitude of this gravity low is compatible with a thick accumulation of Triasssic evaporites in the subsurface. In the southern end of the AG1 profile (Fig. 5b) there is a relative gravity maximum related to a duplication of Jurassic, Lower Cretaceous and Upper Cretaceous rocks due to the Boixols alpine thrust. At the southern part of both cross sections, the depth to the autochthonous deposits (aprox. $5 \mathrm{~km}$ depth) is based on previous geological cross sections by Teixell and Muñoz (2000) and Muñoz et al. (2018).

\section{Discussion}

Cross sections MAL and AG1 show good geological and geophysical constraints at their southern part. Moreover, some points have been refined through the gravity modelling, i.e. the distribution and thickness of the Triassic evaporites (poorly defined in seismic sections). The southern half of the Axial Zone, without available geophysical constraints such as seismic data or wells, has been modelled to infer the volume and geometry at depth of silicic granitic bodies whose density is generally lower than the host rocks (e.g. Vigneresse 1990) and testing the solution of gravity in the tectonic context of the Pyrenean Axial Zone (i.e. system of basement thrust sheets with a complex structure). Even though the density contrast between the granites and the basement is low $\left(2.65 \mathrm{vs} 2.70 \mathrm{~g} / \mathrm{cm}^{3}\right)$ and more constraints are needed to reduce the uncertainty in their geometry, in absence of more geophysical data, gravity data have allowed validating our model of the geometry at depth of granitic bodies and to investigate along-strike structural variations inside the same basement thrust sheets.

\section{Southern axial zone and the inferred geometry at depth of granites}

The residual gravity anomaly along both cross sections highlights a different gravimetric response of the Orri basement thrust sheet with respect to both the Nogueres Zone and the thrust sheet outcropping to the North of the Gavarnie thrust. The outcrop of the Orri basement thrust sheet coincides with a gravity high that can be explained by the absence of the less dense Mesozoic rocks that are covering the Paleozoic basement in the Rialp and Ribagorza basement thrust sheets to the south (Figs. 5, 7). This assumption is compatible with the geometry of the Axial Zone proposed by the ECORSPyrenees profile dominated by an antiformal stack (Muñoz 1992).

Gravity data also reflect the presence of the La Maladeta and Arties granites and also suggest the presence of granitic rocks at depth (under Devonian and Silurian layers in the Aran Valley Syncline) related to the Bossòst granite located to the North (Fig. 7). With respect to the La Maladeta granite, both cross sections show a quite different geometry, the volume of the Maladeta granite in cross section MAL being considerably smaller than in cross-section AG1. The gravity values are compatible with a roughly laccolith geometry with a flat floor tilted towards the North in the cross section MAL, whereas in the cross section AG1 this granite is thicker with a steep floor tilted towards the North (i.e. towards the Gavarnie thrust). These differences could be related to the polydiapirism nature of the Maladeta complex (Leblanc et al. 1994) or simply to a possible originally irregular laccolith geometry. In addition, the cross section MAL crosses the Aneto unit, a well differentiated and concentric normally zoned unit, of the La Maladeta granite that could correspond to the external zones of the possible original laccolith. While the cross section AG1 crosses the larger and more complex zone of the granite, with no regular zoning and constituted by several coalescencing units (Leblanc et al. 1994). This zone could be interpreted as the central part of the laccolith. The deeper root of this granite, close to the Gavarnie thrust, could be associated with the interpretation of this thrust as an old major structure active during late Variscan extensional phases (Soler et al. 1998; Clariana et al. 2009; Teixell et al. 2018). During this period, large structures oriented in a roughly $\mathrm{E}-\mathrm{W}$ direction have been interpreted as structural anisotropies that could facilitate the ascent of magma (Denèle et al. 2008; Clariana 2017). The laccolith geometry interpreted for the La Maladeta granite in cross section MAL could also be favored by the presence of Silurian shales, an effective décollement level introducing a rheological contrast that could help the lateral spread of magma. This behavior has been recognized in the neighboring Marimanha granite (Antolín-Tomás et al. 2009).

\section{Evaporitic accumulation and underthrusting of basement thrust sheets}

The residual anomaly map and the $2.5 \mathrm{D}$ gravity modelling of cross sections MAL and AG1 show a wide negative low ( -17 and $-18 \mathrm{mGal}$ in cross sections AG1 and MAL, respectively) (Fig. 6). This gravity minimum shows an elongated geometry oriented N120E in the residual anomaly map 


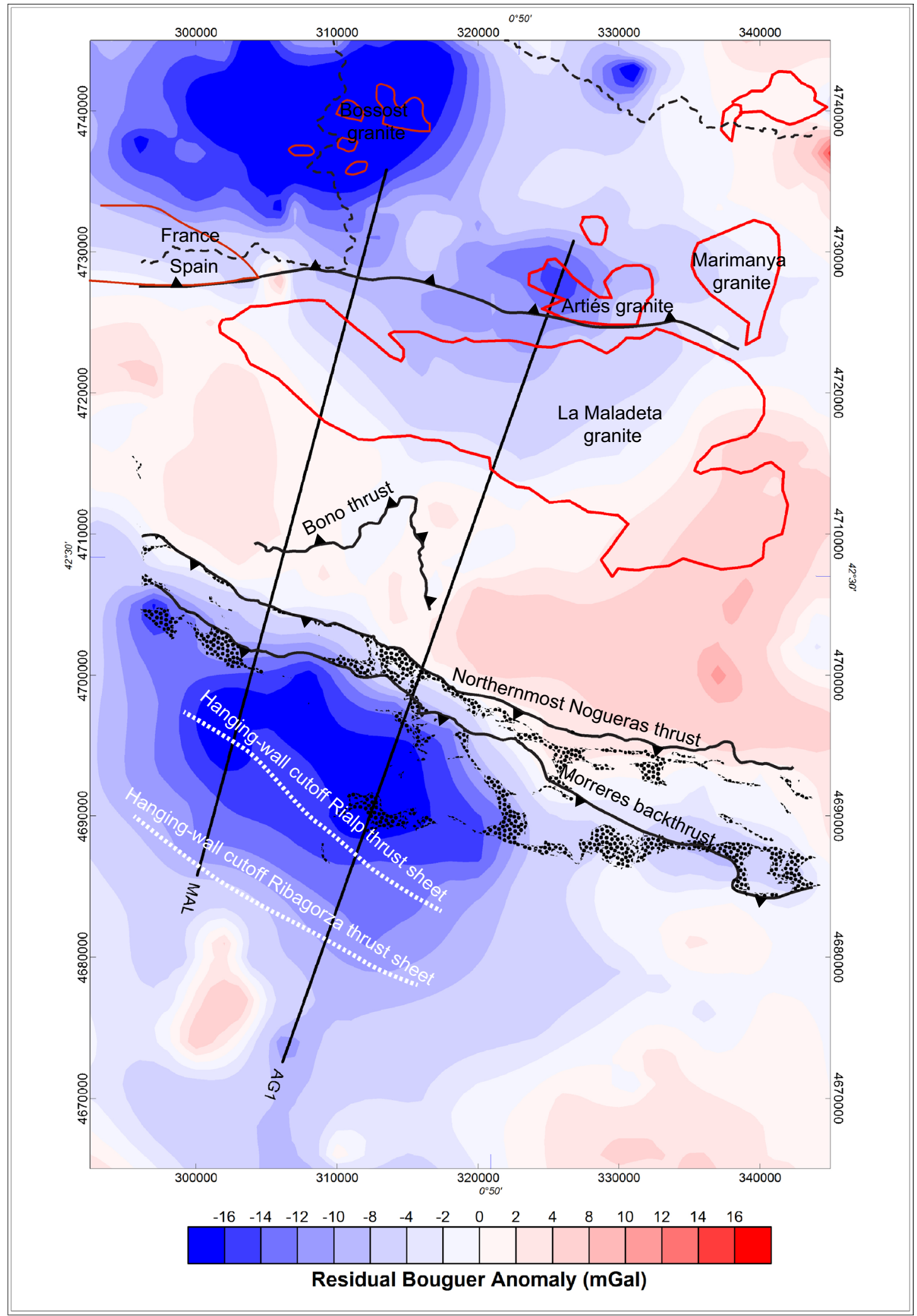

Triassic evaporite outcrops

Granitic body contours

Fig. 7 Main geological structures, boundaries of granite bodies and Triassic evaporites outcrops in the study area drawn on top of the residual Bouguer anomaly map 
and parallel to the main structural trend (Fig. 7). It coincides at surface with large outcrops of Triassic evaporites belonging to the Ribagorza basin and at depth, with the hangingwall cutoff and leading edge of the Rialp basement thrust sheet, also oriented in an approximately N120E direction (Fig. 7). The amplitude of this gravity low is compatible with an important accumulation of Triassic evaporites at depth below the Jurassic and Cretaceous rocks in the Ribagorza basin and also in the Bóixols thrust sheet (Fig. 5). Previous interpretations based on seismic data and wells have already considered an important accumulation of Triassic evaporites at depth in that sector (Muñoz 1992; Teixell and Muñoz 2000; García-Senz 2002; Mencos et al. 2015; Muñoz et al. 2018). Triassic evaporitic accumulations at surface have been interpreted as related with a centrifugal migration of the décollement level from the center of the South Pyrenean Central Unit towards its margins (squeezing) caused by differential loading and shortening during the Mesozoic-Cenozoic syntectonic filling (Soto et al. 2002; Santolaria et al. 2016). Cross sections MAL and AG1 show that the thickest evaporitic accumulation at depth is located above and in front of the leading edge of the Rialp thrust sheet. This feature suggests that the emplacement of the Rialp thrust sheet that occurred during the Oligocene (Muñoz 2002), could favor the accumulation of the décollement level at its southern leading edge.

On the other hand, this area has been recently interpreted as part of a large diapiric province located along the Iberian Margin of the Pyrenean rift and defined by principal E-W and secondary N-S trending diapirs (Saura et al. 2016). These preferential orientations are also reflected by the pattern of the negative residual anomaly distribution over the northernmost part of the South-Pyrenean Zone studied in this work (Fig. 7).

\section{Conclusions}

This work shows that the previous proposed overall structural architecture of the Central Pyrenees is consistent with the observed gravity data in the study area, although some modifications (e. g. the shape and thickness of the evaporitic material) had to be introduced in order to better fit the gravimetric anomalies. The two 2.5D modelled cross sections show similar pattern in the observed gravity data that match well with similar interpreted structures in both cross sections. The observed gravity curves show a gravity high oriented N120E coinciding with the Orri basement thrust sheet and an important gravity depression, also oriented N120E, coinciding with the leading edge at depth of the Rialp basement thrust, which is interpreted in terms of accumulation of salt at base of the Mesozoic sequence. Another result of this work is the geometry at depth of the La Maladeta and Arties granites that have been constrained through gravity modelling. More geophysical data are needed to better constrain that geometry; nonetheless it is a first step towards characterizing the granites of the Central Pyrenees. Moreover, the feedback between geological and gravity data has been useful for constraining the thickness of the different Paleozoic units (Silurian, Devonian and Carboniferous) that form the basement thrust sheets in this part of the Pyrenees.

Supplementary Information The online version contains supplementary material available at https://doi.org/10.1007/s00531-021-02137-2.

Acknowledgements This work is part of the project CGL2017-84901C2-2-P funded by MCIN/AEI/10.13039/501100011033 and "ERDF A way of making Europe" and project PID2020-114273GB-C22 funded by MCIN/AEI/10.13039/501100011033 from Spanish Ministry of Science, Innovation and Universities. Seequent has provided us the GM-SYS module of the Oasis Montaj ${ }^{\circledR}$. The authors acknowledge the contribution of José María Llorente and Agustin González for the acquisition of the gravity data. We thank to Aigüestortes National park and Alt Pirineu Natural park their logistic support. We thank anonymous reviewer for improving the content in the manuscript. This study represents a contribution to GeoAp Research Group (E01-20R) (Aragón Government).

Funding Funding for this work comes from project CGL2017-84901C2-2-P funded by MCIN/AEI/10.13039/501100011033 and "ERDF A way of making Europe" and project PID2020-114273GB-C22 funded by MCIN/AEI/10.13039/501100011033. Open Access funding provided thanks to the CRUE-CSIC agreement with Springer Nature.

Open Access This article is licensed under a Creative Commons Attribution 4.0 International License, which permits use, sharing, adaptation, distribution and reproduction in any medium or format, as long as you give appropriate credit to the original author(s) and the source, provide a link to the Creative Commons licence, and indicate if changes were made. The images or other third party material in this article are included in the article's Creative Commons licence, unless indicated otherwise in a credit line to the material. If material is not included in the article's Creative Commons licence and your intended use is not permitted by statutory regulation or exceeds the permitted use, you will need to obtain permission directly from the copyright holder. To view a copy of this licence, visit http://creativecommons.org/licenses/by/4.0/.

\section{References}

Adam CR (1993). Geophysical investigations of the western Pyrenees. $\mathrm{PhD}$ thesis. University of Bristol, $248 \mathrm{pp}$

Antolín-Tomás B, Román-Berdiel T, Casas-Sainz AM, Gil-Peña I, Soto R (2009) Structural and magnetic fabric study of the Marimanha granite (axial zone of the Pyrenees). Int J Earth Sci 98:427-441. https://doi.org/10.1007/s00531-007-0248-1

Aurell M, Meléndez G (2002) Jurassic: South Pyrenean basin. In: Gibbons W, Moreno MT (eds) The geology of Spain. Geological Society, London, pp 221-233

Ayala C, Rubio FM, Rey-Moral C, Reguera MI, Biete C (2019) Threedimensional geophysical characterization of the La Rambla and Zafra de Záncara anticlines (Loranca Basin, Central Spain). Geophys Prospect 67(3):595-608. https://doi.org/10.1111/13652478.12749 
Ayala C, Rubio FM, Rey-Moral C, Pueyo EL, Clariana P, Soto R, Casas-Sainz AM, Román-Berdiel T, Martí J (2020) Nuevos datos gravimétricos en los Pirineos Centrales (NE de España). Geogaceta 67, pp 103-106. ISSN (print version): 0213-683X. ISSN (Internet): 2173-6545

Barnolas A, Gil-Peña I (2001) Ejemplos de relleno sedimentario multiepisódico en una cuenca de antepaís fragmentada: La Cuenca Surpirenaica. Bol Geol Min 112:17-38

Barnolas A, Chiron JC, Guérangé B (1996) Synthèse géologique et géophisique des Pyrénées. Volume 1, Introduction, geophysique, cycle hercynien. Éditions BRGM-ITGE, 729 pp., 26pl. h.t

Beamud E, Muñoz JA, Fitzgerald PG, Baldwin SL, Garcés M, Cabrera L, Metcalf JR (2011) Magnetostratigraphy and detrital apatite fission track thermochronology in syntectonic conglomerates: constraints on the exhumation of the South-Central Pyrenees. Basin Res 23(3):309-331

Beaumont C, Muñoz JA, Hamilton J, Fullsack P (2000) Factors controlling the alpine evolution of the Central Pyrenees inferred from a comparison of observations and geodynamical models. J Geophys Res 105(B4):8121-8145

Bond RMG, McClay KR (1995) Inversion of a lower cretaceous extensional basin, south central Pyrenees, Spain. In: Buchanan JG, Buchanan PG (eds) Geological Society Spec. Publ. 88, pp 415-431

Calvín P, Santolaría P, Casas-Sainz AM, Pueyo EL (2018) Detachment fold vs. ramp anticline: a gravity survey in the southern Pyrenean front (external sierras). Geol J 53(1):178-190

Casas A, Kearey P, Rivero L, Adam CR (1997) Gravity anomaly map of the Pyrenean region and a comparison of the deep geological structure of the western and eastern Pyrenees. Earth Planet Sci Lett 150:65-78

Chevrot S, Villaseñor A, Sylvander M, The Pyrope Team (2014) High resolution imaging of the Pyrenees and Massif Central from the data of the PYROPE and IBERARRAY portable array deployments. J Geophys Res 119(8):6399-6420. https://doi.org/10. 1002/2014JB010953

Chevrot S, Sylvander M et al (2018) The noncylindrical crustal architecture of the Pyrenees. Sci Rep 8:9591. https://doi.org/10.1038/ s41598-018-27889-x

Chokroune and ECORS Team (1989) The ECORS deep seismic profile reflection data and the overall structure of an orogenic belt. Tectonics 8:23-39

Clariana P (2017) Estratigrafía, estructura y su relación con el metamorfismo de la Zona Axial pirenaica en la transversal del noroeste de Andorra y comarcas del Pallars Sobirá y el Alt Urgell (Lleida). Publicaciones especiales del IGME, Serie tesis doctorales, p 195

Clariana P, García-Sansegundo J, Gavaldá J (2009) The structure in the Bagneres de Luchon and Andorra cross sections (axial zone of the central Pyrenees). Trabajos Geol 29:175-181

Cochelin B, Lemirre B, Denèle Y, de Saint BM, Lahfid A, Duchêne S (2017) Structural inheritance in the central Pyrenees: the Variscan to alpine tectonometamorphic evolution of the axial zone. $\mathrm{J}$ Geol Soc Lond. https://doi.org/10.1144/jgs2017-066

Debon F, Enrique P, Autran A (1996) Magmatisme hercyniene. In: Barnolas A, Chiron JC (eds) Synthèse géologique at géophysique des Pyrénées, vol 1. BRGM. ITGE, Orléans, Madrid, pp 361-500

Denèle Y, Olivier P, Gleizes G (2008) Progressive deformation of a zone of magma transfer in a transpressional regime: the Variscan Mérens shear zone (Pyrenees, France). J Struct Geol 30:11381149. https://doi.org/10.1016/j.jsg.2008.05.006

Déramond J, Baby P, Specht M, Crouzet G (1988) Géometrie des chevauchements dans la Zone nord-pyrénéenne ariégeoise précisée par le profil ECORS. Bull Soc Géol France 8(6):287-294
Devolvé JJ (1987) Un bassin synorogénique varisque. Le Culm des Pyrénées centro-occidentales. PhD Thesis. University of Toulouse

Espurt N, Angrand P, Teixell A, Labaume P, Ford M, de Saint BM, Chevrot S (2019) Crustal-scale balanced cross-section and restorations of the Central Pyrenean belt (Nestes-Cinca transect): highlighting the structural control of Variscan belt and PermianMesozoic rift systems on mountain building. Tectonophysics 764:25-45

Esteban JJ, Aranguren A, Cuevas J, Hilario A, Tubia JM, Larionov A, Sergeev $S$ (2015) Is there a time lag between the metamorphism and emplacement of plutons in the Axial Zone of the Pyrenees? Geol Mag 152(5):935-941

Evans NG (1993). Deformation during the emplacement of the Maladeta granodiorite Spanish Pyrenees. PhD thesis, University of Leeds

García-Sansegundo J (1990) Structure of the Paleozoic in the Aran Valley, axial zone, central Pyrenees. Bull Soc Géol France Paris (8) 2:229-239

García-Sansegundo (1992) Estratigrafía y estructura de la Zona Axial pirenaica en la transversal del Valle de Aran y de la Alta Ribagorça. Publicaciones especiales del Boletín Geológico y Minero, $167 \mathrm{pp}$

García-Sansegundo J (1996) Hercynian structure of the axial zone of the Pyrenees: the Aran Valley cross-section (Spain-France). J Struct Geol 18:1315-1325

García-Sansegundo J, Ramírez Merino JI (2013) Mapa Geológico de España E. 1:50.000, Hoja no 118bis-148 (Caneján-Viella), 2a Serie MAGNA. Instituto Geológico y Minero de España, Madrid

García-Sansegundo J, Gavaldá J, Alonso JL (2004) Preuves de la discordance de l' Ordovicien supérieur dans la Zone Axiale des Pyrénées: exemple du Dôme de la Garonne (Espagne, France). Comp Rendus Geosci 336:1035-1040

García-Sansegundo J, Poblet J, Alonso JL, Clariana P (2011) Hinterland-foreland zonation of the Variscan orogen in the Central Pyrenees: comparison with the northern part of the Iberian Variscan Massif. In: Poblet J, Lisle RJ (eds) Kinematic evolution and structural styles of fold-and-thrust belts, vol 349. Geological Society Special Publications, London, pp 169-184

García-Senz J (2002). Cuencas extensivas del Cretácico Inferior en los Pirineos centrales: formación y subsecuente inversión. PhD thesis, University of Barcelona, Barcelona, Spain, $310 \mathrm{pp}$

García-Senz J, Ramirez-Merino JI (2009) Mapa Geológico de España E. 1:50.000, Hoja no 213 (El Pont de Suert), $2^{\mathrm{a}}$ Serie MAGNA. Instituto Geológico y Minero de España, Madrid

García-Senz J, Pedrera A, Ayala C, Ruiz-Constan A, Robador A, Rodríguez-Fernandez LR (2019) Inversion of the north Iberian hyperextended margin: the role of exhumed mantle indentation during continental collision. In: Hammerstein JA, Di Cuia R, Cottam MA, Zamora G, Butler RWH (eds) Fold and thrust belts: structural style, evolution and exploration. Geological Society Special Publications, London, p 490

Garrido-Megías A (1973). Estudio geológico y relación entre tectónica y sedimentación del Secundario y Terciario de la vertiente meridional pirenaica en su zona central (provincias de Huesca y Lerida). PhD thesis, University of Granada, pp 1-395

Gil-Peña I (2004) Estructura alpina de la Zona Axial. In: Vera J (ed) Geología de España. SGE-IGME, Madrid, p 241

Gil-Peña I, Barnolas A (2001) Superposición estructural hercínica y alpina en el borde occidental del domo de Pallassos (Noguera de Tor, Pirineo central). Bol Geol Miner Esp 112(3):5-16

Gisbert J (1983) El Pérmico de los Pirineos españoles. In: MartínezDíaz C (ed) Carbonífero y Pérmico de España. Publicaciones del Instituto Geológico y Minero de España, Madrid, pp 405-420 
Goleby BR, Shaw RD, Wright C, Kennett BL, Lambeck K (1989) Geophysical evidence for "thick-skinned" crustal deformation in central Australia. Nature 337(6205):325-330. https://doi.org/ $10.1038 / 337325 \mathrm{a} 0$

Gutierrez-Medina M (2007) Nuevas aportaciones al conocimiento de la estructura varisca y alpina de la lámina cabalgante de Bono, Zona Axial, Pirineos Centrales. Trabajos Geol 27:159-177

Institut Cartogràfic y Geològic de Catalunya (ICGC )(2010) Actualització del model de dades gravimètriques per a la publicació del mapa gravimètric de Catalunya 1:250.000(OC/2010/390) IGC-GA-022/2010, 25 pp

Institut Cartogràfic y Geològic de Catalunya (ICGC) (2016) Mapa geológico comarcal 1:50000 de Cataluña, used under license CC by 4.0

Izquierdo-Llaval E, Casas-Sainz AM, Oliva-Urcia B (2013) Heterogeneous deformation recorded by magnetic fabrics in the Pyrenean axial zone. J Struct Geol 57:97-113. https://doi.org/ 10.1016/j.jsg.2013.10.005

Izquierdo-Llavall E, Casas-Sainz AM, Oliva-Urcía B, Villalain JJ, Pueyo EL, Scholger R (2018) Rotational kinematics of basement antiformal stacks: paleomagnetic study of the Western Nogueras zone (central Pyrenees). Tectonics 37(10):34563478. https://doi.org/10.1029/2018TC005153

Izquierdo-Llavall E, Ayala C, Pueyo EL, Casas-Sainz AM, OlivaUrcia B, Rubio F, Rodríguez-Pinto A, Rey-Moral C, Mediato JF, García-Crespo J (2019) Basement-cover relations and their along-strike changes in the linking zone (Iberian range, Spain): a combined structural and gravimetric study. Tectonics 38:2934-2960. https://doi.org/10.1029/2018TC005422

Jammes S, Tiberi C, Manatschal G (2010) 3D architecture of a complex transcurrent rift system: the example of the Bay of Biscay-Western Pyrenees. Tectonophysics 489:210-226

Kane MF (1962) A comprehensive system of terrain corrections using a digital computer. Geophysics 27(4):455-462

Labaume P, Meresse F, Jolivet M, Teixell A, Lahfid A (2016) Tectonothermal history of an exhumed thrust-sheet-top basin: an example from the south Pyrenean thrust belt. Tectonics 35(5):1280-1313

Lago M, Galé C, Arranz E, Vaquer R, Gil A, Pocoví A (2000) Triassic tholeiitic dolerites ("ophites") of the El Grado diapir (Pyrenees, Huesca, Spain): emplacement and composition. Estud Geol $56: 3-18$

Lago San José M, Pocoví-Juan A (1980) Observaciones petrográficas y tectónicas sobre las ofitas del área de Aulet (Prepirineo meridional, prov. de Huesca). Acta Geol Hisp 15(5):141-151

Lanaja JM (ed) (1987) Contribución de la exploración petrolífera al conocimiento de la geología de España. IGME, Madrid

Laumonier B (2015) Les Pyrénées alpines sud-orientales (France, Espagne)—essai de synthèse. Rev Géol Pyrénéene 2015(2):1-44

Leblanc D, Gleizes G, Lespinasse P, Olivier Ph, Bouchez JL (1994) The maladeta granite polydiapir, Spanish Pyrenees: a detailed magnetostructural study. J Struct Geol 16(2):223-235. https:// doi.org/10.1016/0191-8141(94)90106-6

Ledo J, Ayala C, Pous J, Queralt P, Marcuello A, Muñoz JA (2000) New geophysical constrains on the deep structure of the Pyrenees. Geophys Res Lett 27:1037-1040

López-Olmedo F, Ardèvol L (2016) Mapa Geológico de España E. 1:50.000, Hoja no 251 (Arén), $2^{\text {a }}$ Serie MAGNA. Instituto Geológico y Minero de España, Madrid

López-Sánchez M, García-Sansegundo J, Martínez F (2019) The significance of early Permian and early Carboniferous $\mathrm{U}-\mathrm{Pb}$ zircon ages in the Bossòst and Lys-Caillaouas granitoids (Pyrenean Axial Zone). Geol J 54(4):2048-2063. https://doi.org/10.1002/ gj. 3283
Martínez-Peña MB, Casas-Sainz AM (2003) Cretaceous-tertiary tectonic inversion of the Cotiella Basin (southern Pyrenees, Spain). Int J Earth Sci 92:99-113

Martín-Parra LM, Bellido F, Rodríguez-Fernández LR, Suárez A, Zamora G (2016) Mapa Geológico de España E. 1:50.000, Hoja no 181 (Esterri de Aneu), 2 ${ }^{\text {a }}$ Serie MAGNA. Instituto Geológico y Minero de España, Madrid

Mattauer M (1968) Les traits structuraux essentiels de la chaîne pyrénéenne. Rev Géogr Phys Géol Dyn 10(1):3-12

Matte P (1969) Le problème du passage de la schistosité horizontale à la schistosité verticale dans le dôme de Garonne (Paléozoique des Pyrénées Centrales). Comp Rendus Acad Sci Paris 268:1841-1844

McCulloh TH (1965) A confirmation by gravity measurements of an underground density profile based on core densities. Geophysics 30:1108-1132

Mencos J, Carrera N, Muñoz JA (2015) Influence of rift basin geometry on the subsequent postrift sedimentation and basin inversión: the Organyà Basin and the Bóixols thrust sheet (south central Pyrenees). Tectonics 34(7):1452-1474. https://doi.org/10.1002/ 2014TC003692

Mey PHW (1967) The geology of the upper Ribagorzana and Baliera valleys, Central Pyrenees, Spain. Leidse Geol Meded 41:153-220

Mey PHW, Nagtegaal PJC, Roberti KL, Hartevelt JJA (1968) Lithostratigraphic subdivision of post-hercynian deposits in the South-Central Pyrenees, Spain. Leids Geol Meded 41:221-228

Mezger JE, Gerdes A (2016) Early Variscan (Visean) granites in the core of central Pyrenean gneiss domes: Implications from laser ablation U-Pb and Th-Pb studies. Gondwana Res 29(1):181-198

Muñoz JA (1992) Evolution of a continental collision belt: ECORSPyrenees crustal balanced cross-section. In: McClay KR (ed) Thrust tectonics. Chapman and Hall, London, pp 235-246

Muñoz JA (2002) The Pyrenees. In: Gibbons W, Moreno T (eds) The geology of Spain. The Geological Society of London, London, pp 370-385

Muñoz JA, Martínez A, Vergés J (1986) Thrust sequences in the Eastern Spanish Pyrenees. J Struct Geol 8(3/4):399-405

Muñoz JA, Mencos J, Roca E, Carrera N, Cratacós O, Ferrer O, Fernández O (2018) The structure of the South-Central-Pyrenean fold and thrust belt as constrained by subsurface data. Geol Acta 16(4):439-460. https://doi.org/10.1344/GeologicaActa20 18.16.4.7

Nagy D (1966) The prism method for terrain corrections using digital computers. Pure Appl Geophys 63:31-39

Parish M (1984) A structural interpretation of a section of the Gavarnie nappe and its implications for Pyrenean Geology. J Struct Geol 6:247-255

Pedrera A, García-Senz J, Ayala C, Ruiz-Constán A, RodríguezFernández LR, Robador A, González-Menéndez L (2017) Reconstruction of the exhumed mantle across the North-Iberian Margin by crustal-scale 3D gravity inversion and geological cross section. Tectonics 36:3155-3177. https://doi.org/10.1002/ 2017TC004716

Pedrera A, García-Senz J, Ayala C, Ruiz-Constán A, RodríguezFernández LR, Robador A, González-Menéndez L (2018) Reply to comment by Pedreira et al. reconstruction of the exhumed mantle across the North-Iberian Margin by crustal-scale 3D gravity inversion and geological cross-section'. Tectonics 37:43464356. https://doi.org/10.1029/2018TC005222

Poblet J (1991). Estructura herciniana i alpina del Vessant sud de la zona Axial del Pirineu Central. Unpublished PhD thesis, Univ. of Barcelona, $604 \mathrm{pp}$

Pueyo EL, Izquierdo-Lavall E, Rodríguez-Pintó A, Rey Moral C, OlivaUrcia B, Casas AM, Calvín P, Ayala C, del Rio P, Ramajo J, García-Lobón JL, Rubio F (2016) Petrophysical properties in 
the Iberian Range and surrounding areas (NE Spain): 1-density. J Maps 12(5):836-844. https://doi.org/10.1080/17445647.2015. 1084545

Puigdefàbregas C, Souquet P (1986) Tecto-sedimentary cycles and depositional sequences of the mesozoic and tertiary from the Pyrenees. Tectonophysics 129(1-4):173-203

Puigdefàbregas C, Muñoz JA, Vergés J (1992) Thrusting and foreland basin evolution in the Southern Pyrenees. In: Mcclay KR (ed) Thrust tectonics. Chapman and Hall, London, pp 247-254. https://doi.org/10.1007/978-94-011-3066-021

Pujalte V, Schmitz B (2005) Revisión de la estratigrafía del Grupo Tremp ("Garumniense", Cuenca de Tremp-Graus, Pirineos meridionales). Geogaceta 38:79-82

Ríos-Aragües LM, Galera-Fernández JM, Barettino D, Charlet JM (2002) Mapa Geológico de España E. 1:50.000, Hoja n ${ }^{\circ} 180$ (Benasque), $2^{\text {a }}$ Serie MAGNA. Instituto Geológico y Minero de España, Madrid

Roca E, Muñoz JA, Ferrer O, Ellouz N (2011) The role of the Bay of Biscay Mesozoic extensional structure in the configuration of the Pyrenean orogen: constraints from the MARCONI deep seismic reflection survey. Tectonics 30:TC2001. https://doi.org/10.1029/ 2010TC002735

Rosell J (1994) Mapa Geológico de España E. 1:50.000, Hoja n ${ }^{\circ} 252$ (Tremp), $2^{a}$ Serie MAGNA. Instituto Geológico y Minero de España, Madrid

Roure F, Choukroune P et al (1989) ECORS deep seismic data and data and balanced cross-sections: geometric constraints on the evolution of the Pyrenees. Tectonics 8:41-50. https://doi.org/10. 1029/TC008i001p00041

Santolaria P, Casas-Sainz AM, Soto R, Casas A (2016) Gravity modelling to assess salt tectonics in the western end of the South Pyrenean Central Unit. J Geol Soc 174:269-288. https://doi.org/ 10.1144/jgs2016-027

Santolaria P, Ayala C, Pueyo EL, Rubio FM, Soto R, Calvin P, Luzón A, Rodríguez-Pintó A, Oliván C, Casas-Sainz AM (2020) Structural and geophysical characterization of the western termination of the South Pyrenean triangle zone. Tectonics. https://doi.org/ 10.1029/2019TC005891

Sanz-López J, Palau J (2013). Mapa Geológico de España E. 1:50.000, Hoja $^{\circ} 149$ (Isil), $2^{\text {a }}$ Serie MAGNA. Instituto Geológico y Minero de España, Madrid

Saura E (2004) Anàlisi estructural de la zona de les Nogueres Pirineus Centrals. Universitat Autònoma de Barcelona, Tesi Doctoral, p 355

Saura E, Teixell A (2006) Inversion of small basins: effects on structural variations at the leading edge of the axial zone antiformal stack (Southern Pyrenees, Spain). J Struct Geol 28:1909-1920

Saura E, Ardévol LI, Teixell A, Vergés J (2016) Rising and falling diapirs, shifting depocenters and flap overturning in the cretaceous Sopeira and Sant Gervàs subbasins (Ribagorça basin, Pyrenees). Tectonics 35:638-662

Séguret M (1972). Etude tectonique des nappes et séries décollées de la partie centrale du versant sud des Pyrénées. Caractère synsédimentaire, rôle de la compression et de la gravité. Univ. de Montpellier, $150 \mathrm{p}$ (PhD thesis)

Simó A (1986) Carbonate platform depositional sequences, upper cretaceous, south-central Pyrenees (Spain). Tectonophysics 129:205-231

Simó A (2004) El Cretácico superior de la Unidad Surpirenaica Central. In: Vera JA (ed) Geología de España. Sociedad Geológica de España-Instituto Geológico y Minero de España, Spain, pp 296-299

Solé J, Soler A, Palau J, Espiuola MP, Delgado J (1997) Geocronología $\mathrm{K} / \mathrm{Ar}$ de los Skarn Mineralizados en As-Au y de las alteraciones intragraníticas asociadas en el Hercínico de los Pirineos centrales. Bol Soc Esp Mineral 20A:77-78

Soler D, Teixell A, García-Sansegundo J (1998) Amortissement latéral du chevauchement de Gavarnie et sa relation avec les unités sudpyrénéenes. Comp Rendus Acad Sci Paris 327:699-704

Soto R, Casas AM, Storti F, Faccenna C (2002) Role of lateral thickness variations on the development of oblique structures at the western end of the South Pyrenean Central Unit. Tectonophysics 350:215-235

Talwani M, Worzel JL, Landisman M (1959) Rapid gravity computations for two dimensional bodies with application to the Mendocino submarine fracture zone. J Geophys Res 64(1):49-59. https://doi.org/10.1029/JZ064i001p00049

Teixell A (1996) The Ansó transect of the southern Pyrenees: basement and cover thrust geometries. J Geol Soc Lond 153:301-310

Teixell A, Muñoz JA (2000) Evolución tectono-sedimentaria del Pirineo meridional durante el Terciario: una síntesis basada en la transversal del río Noguera Ribagorçana. Rev Soc Geol Esp 13:295-316

Teixell A, Labaume P, Ayarza P, Espurt N, Saint Blanquat M, Lababrielle Y (2018) Crustal structure and evolution of the PyreneanCantabrian belt: a review and new interpretations from recent concepts and data. Tectonophysics 724-725:146-170. https:// doi.org/10.1016/j.tecto.2018.01.009

Torné M, de Cabissole B, Bayer R, Casas A, Daignières M, Rivero A (1989) Gravity constraints on the deep structure of the Pyrenean belt along the ECORS profile. Tectonophysics 165:105-116

Torné M, Fernàndez M, Vergés J, Ayala C, Salas MC, Jimenez-Munt Y, Buffet GG, Díaz J (2015) Crust and mantle lithospheric structure of the Iberian Peninsula deduced from potential field modeling and thermal analysis. Tectonophysics 663:419-433

Vacher P, Souriau A (2001) A three-dimensional model of the Pyrenean deep structure based on gravity modelling, seismic images and petrological constraints. Geophys J Int 145:460-470

Vergés J (1993). Estudi geològic del vessant sud del Pirineu oriental i central. Evolució cinemàtica en 3D. PhD thesis. Univ. de Barcelona, $192 \mathrm{p}$

Vergés J, Muñoz JA (1990) Thrust sequences in the southern central Pyrenees. Bull Soc Géol France 6(2):265-271

Vergés J, Millán H, Roca E, Muñoz JA, Marzo M, Cirés J, Den Bezemer T, Zoetemeijer R, Cloetingh S (1995) Eastern Pyrenees and related foreland basins: pre-, syn- and post-collisional crustalscale cross-sections. Mar Pet Geol 12:893-915

Wehr H, Chevrot S, Gourrioux G, Guillen A (2018) A three-dimensional model of the Pyrenees and their foreland basins from geological and gravimetric data. Tectonophysics 734-735:16-32

Williams GD (1985) Thrust tectonics in the south central Pyrenees. J Struct Geol 7(1):11-17

Won IJ, Bevis M (1987) Computing the gravitational and magnetic anomalies due to a polygon: algorithms and fortran subroutines. Geophysics 52(2):232-238. https://doi.org/10.1190/1.1442298

Zwart HJ (1979) The geology of the Central Pyrenees. Leidse Geol Meded 50:1-74

Zwart HJ (1986) The variscan geology of the Pyrenees. Tectonophysics 129:9-27 